\title{
A Chelating Resin Containing \\ 2-(2-Thiazolylazo)-5-dimethylaminophenol as the Functional Group: Synthesis and Sorption Behavior for Some Trace Metal Ions
}

\author{
Won Lee, ${ }^{*}$ Si-Eun Lee, Mi-Kyoung Kim, Chang-Heon Lee, ${ }^{\dagger}$ and Young-Sang Kim ${ }^{*}$ \\ Research Instime for Basic Sciences and Department of Chemisty, Kymghee Lniversity, Seonl 130-701, Norea

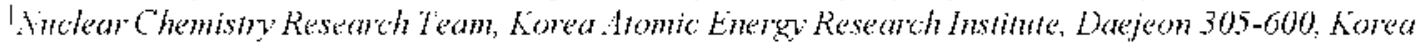 \\ Depatment of Chemistry. Korea Lniversitw, tochinon 339-700, Korea \\ Received ipril +. 2002
}

\begin{abstract}
$\Lambda$ new polystyrene-divinylbenzene resin containing 2-(2-thiazolylazo)-5-dimethylamino-phenol (IAM) functional groups has been sinthesized and its sorption thehavior for nineteen metal ions, including $\operatorname{Lr}(\mathrm{IV})$, I If(IV) and U(VI) has been investigated by batch and column methods. The chelating resin showed high sorption aftinity for $\angle \mathrm{r}(\mathrm{IV})$ at $\mathrm{pl} \mathrm{l}-5$ and $\mathrm{U}(\mathrm{VI})$ at $\mathrm{pll} 4$. Some parameters aftecting the sorption of the metal ions have been detailed. The breakthrough and overall capacities were measured under optimized conditions. The overall capacities of ' $\mathrm{Cr}(\mathrm{IV})$, Ih(IV) and U(VI), which showed higher than the other metal ions, were 0.90 , 0.84 and $0.80 \mathrm{mmol} / \mathrm{g}$. respectively. The elution order of metal ions at $\mathrm{pI} 4 \mathrm{f}$ was evaluated as $\angle \mathrm{r}(\mathrm{IV})>\mathrm{Th}(\mathrm{IV})$ $>\mathrm{U}(\mathrm{VI})>\operatorname{Cu}(\mathrm{II})>\mathrm{IIf(IV)}>\mathrm{W}(\mathrm{VI})>\mathrm{Mo}(\mathrm{VI})>\operatorname{In}(\mathrm{III})>\operatorname{Sn}(\mathrm{IV})>\operatorname{Cr}(\mathrm{II})>\mathrm{V}(\mathrm{V})>\mathrm{Fe}(\mathrm{III})$. Quantitative recorery of most metal ions except $\angle \mathrm{r}$ (IV) was achieved using $2 \mathrm{M} \mathrm{IINO}$. Desorption and recovery of $\angle \mathrm{r}$ (IV) was successfully perfomed with $2 \mathrm{M} \mathrm{IIClO}_{1}$ and $2 \mathrm{MIICl}$.
\end{abstract}

Key words : Chelating resin, 2-(2-Thiazoly lazo)-5-dimethylaminophenol, Sorption behavior, Column method

\section{Introduction}

Recently, for high sensitivity good reproducibility and a wide dy namic concentration range inductively coupled plasma atomic emission spectrometry (ICP-AES) and inductively coupled plasma mass spectrometry (ICP-MS) have been widely selected as the technique of choice to perform the analysis of trace amounts of metal ions. However, separation and preconcentration of trace levels of metal ions are indispensable because spectral interference is found in the intensively complex atomic emission spectra of matrices of various sample. such as metal alloys and ores. Many separation techniques using solvent extraction and ion exchange chromatoraphy have been applied to this the purpose. Ion exchange is a popular method owing to its applicability to both preconcentration and separation. But. for the lack of selective separation a new method using various chelating resins has worked. ${ }^{1-6}$ This method has good sorption ability of ion exchange in the trace and ultra trace concentration range.' A study on the synthesis and sorption characterization of chelating resins available for interesting metal ions has been extensively carried out. ${ }^{4-?}$ Lee and others reported that TAR-XVI has a relatively high sorption selectivity for U(VI) and rapid sorption." And we previously reported that polysty renediviny lbenzene resin containing 1-(2-thiazoly lazo)-2-naphthol (TAN) has a high sorption affinity for $\mathrm{Zr}(\mathrm{IV})$ and $\mathrm{Hf}(\mathrm{IV})$ at $\mathrm{pH} 2 .^{8}$

Interest has been shown in any fractionation between $\mathrm{Zr}$ and $\mathrm{Hf}$ in geochemistry and cosmochemistry: Because the

"Comesponding Author. Fax: +82-2-968-6584: s-mail: wonlec' khu.ac.kr change in the $\mathrm{Zr} / \mathrm{Hf}$ ratio may be interpreted as a reflection of a change in the geochemical or cosmochemical environment. $^{9-1 i}$ But $\mathrm{Zr}$ and $\mathrm{Hf}$ have very similar chemical properties due to their identical atomic and ionic radii and the sorption behavior of $\mathrm{Zr}$ is very similar to $\mathrm{Hf}$. which makes them difficult to separate from each other.

This paper describes the synthesis, characterization and metal sorption characteristics of new chelating sorbent. XAD-16-TAM. obtained by the introduction of 2-(2-thiazolylazo)-5-dimethyl-aminophenol (TAM) as a complexing functional group into polysty rene-divinylbenzene copolymer. Amberlite XAD-16. The commercially available Amberlite $\mathrm{XAD}$ copolymers have been widely used as absorbents suitable for reconcentration of multielements from aqueous solution. having a high surface area. uniform pore distribution and rigid porous structure. Because $\mathrm{XAD}-16$ resin has the largest surface area $\left(800 \mathrm{~m}^{2} / \mathrm{g}\right)$ in XAD series. it was used as matrix of chelating sorbent. On the basis of selective chelate forming for $\mathrm{Zr}$ and $\mathrm{Hf}$, we had paid attention to TAM, which acts as a tridentate ligand toward metal ions and a metalindicator in complexometric titrations. . i. $-1.5^{-5}$

In this study, a new chelating sorbent was synthesized by coupling TAM with a diazotized XAD-16. The chelate formation of metal ion with TAM is shown in Figure 1. For the selective separation of $\mathrm{Hf}(\mathrm{IV})$. $\mathrm{Zr}$ (IV) and U(VI) from a material related to the nuclear fuel cycle, sea water. wastewater and geological material. the sorption and desorption behaviour of XAD-16-TAM on the nineteen metal ions. including $\mathrm{Zr}(\mathrm{IV})$. $\mathrm{Hf}(\mathrm{IV})$ and $\mathrm{U}(\mathrm{VI})$ were investigated by batch and column methods. 


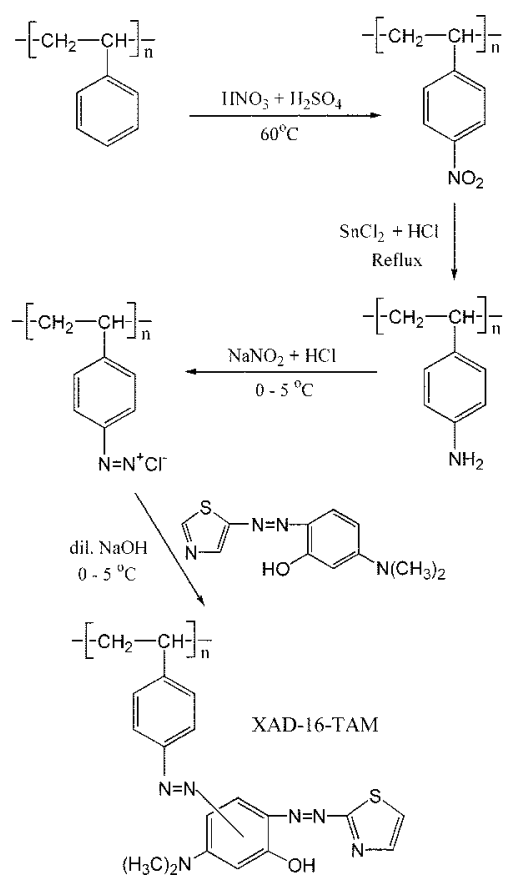

Figure 1. Schematic diagram for Synthesis of XAD-16-lAM chelating resin.

\section{Experimental Section}

Apparatus. The concentrations of metal ions were determined by inductively coupled plasma atomic emission spectrometer (IRIS/AP. Thermo-Jarrel Ash). Functional groups of intermediates and a final chelating resin taken in the synthesis process were identified with a FT-lR spectrometer (IFS 28. Bnuker). Elemental analysis was carried out using elemental analyzer (Eager 200. CEst).

Materials. Amberlite XAD-16 resin (wet density: 1.02 $\mathrm{g} / \mathrm{mL}$. surface area: $800 \mathrm{~m}^{2} / \mathrm{g}$. ave. pore diameters 100 purchased from Aldrich (USA). The 100-200 mesh resin was washed with $\mathrm{H}_{2} \mathrm{O}$-methanol $(70 / 30$. v/v), $2 \mathrm{M} \mathrm{NaOH}-$ methanol (50/50. v/v). $\mathrm{H}_{2} \mathrm{O}$-methanol (50/50. v/v). $2 \mathrm{M} \mathrm{HCl}$ methanol $(50 / 50, \mathrm{v} / \mathrm{v})$. THF-methanol $(50 / 50, \mathrm{v} / \mathrm{v})$. acetone. methanol and finally with $\mathrm{H}_{2} \mathrm{O}$-methanol $(50 / 50$, v/v). The resin was dried in a vacuum oven at $60{ }^{\circ} \mathrm{C}$ and stored in a polyethylene bottle. 2-(2-thiazoly lazo)-5-dimethy laminophenol (TAM) was purchased from Sigma. XAD-16-TAM chelating resin was prepared as described previously " Metal ion solutions were prepared by diluting ICP standard solutions ( $1000 \mu \mathrm{g} / \mathrm{mL}$. Accu Standard). All the chemicals were used analytical reagent grade. Water was obtained from the Milli$\mathrm{Q} /$-RO reagent water purification sy stem (Millipore Ltd.).

Chemical stability of the resin. $1-5 \mathrm{M} \mathrm{HCl}$ and $\mathrm{NaOH}$ solutions were added to the polyethylene bottle containing $30 \mathrm{mg}$ of XAD-16-TAM. It was shaken continuously for 7 days. filtered off and washed with distilled water until neutral. After drying. the sorption capacity for $\mathrm{Cu}(\mathrm{II})$ was measured by using the batch equilibrium method.

Sorption studies. The sorption behavior of XAD-16TAM for Zr(IV). Th(IV). U(VI). Cu(II). Hf(IV). W(VI). Mo (VI), $\ln (\mathrm{III}), \mathrm{Sn}(\mathrm{IV}) . \mathrm{Cr}(\mathrm{III}), \mathrm{V}$ (V). $\mathrm{Fe}(\mathrm{III}), \mathrm{Ta}(\mathrm{V}) . \mathrm{Nb}(\mathrm{V})$.
$\mathrm{Co}(\mathrm{II}), \mathrm{Mn}(\mathrm{II}), \mathrm{Ni}(\mathrm{II}) . \mathrm{Pb}(\mathrm{II}) . \mathrm{Zn}(\mathrm{II})$ were studied by batch and column methods.

Effect of pH on the sorption of metal ions. Fifty milligrams of the resin were shaken with $50 \mathrm{~mL}$ of the mixed solution containing $10 \mu \mathrm{g} / \mathrm{mL}$ of each metal ion at $\mathrm{pH} 1-6$. The $\mathrm{pH}$ of the solution was adjusted to the desired value with hydrochloric acid or ammonia solution. After 24 luss. the residual concentrations of the metal ions were measured by ICP-AES.

Kinetics of the sorption of metal ions on XAD-16-TAM. Thirty milligrams of the resin were shaken with $30 \mathrm{~mL}$ of $0.01 \mathrm{M}$ acetate buffer solution $(\mathrm{pH} 3)$ containing $10 \mu \mathrm{g} / \mathrm{mL}$ of the $\operatorname{Zr}$ (IV). Aliquots of the solutions were withdrawn at various intervals and the residual concentration of the $\operatorname{Zr}(\mathrm{IV})$ was measured.

Effect of masking agent on the sorption of metal ions. Fifty milligrams of the resin were shaken with $50 \mathrm{~mL}$ of 0.01 $\mathrm{M}$ acetate buffer solution $(\mathrm{pH}+$ ) containing $10 \mu \mathrm{g} / \mathrm{mL}$ of each metal ion and $0.5-10 \mathrm{mM}$ of the ethylenediaminetetracetic acid (EDTA). cyclohexanediaminetetra acetic acid (CDTA) and nitrilotriacetic acid (NTA) as a masking agent, respectively. After $2+$ hrs, the residual concentrations of the metal ions were measured

Breakthrough experiment. For the column experiment. 5 $\mu \mathrm{g} / \mathrm{mL}$ of the mixed metal solution buffered to $\mathrm{pH}+$ was passed through polyacryl columm $(0.4 \times 5 \mathrm{~cm})$, packed with $100 \mathrm{mg}$ of the resin suspended in distilled water and preconditioned with the $0.01 \mathrm{M}$ acetate buffer solution $(\mathrm{pH}$ 4). The solution was eluted at a flow rate of $0.2 \mathrm{~mL} / \mathrm{min}$. The effluent fractions were collected in $5 \mathrm{~mL}$ portions and analyzed for the presence of the metal.

Desorption studies. The mixed metal solution containing $5 \mu \mathrm{g} / \mathrm{mL}$ of each metal ion was prepared with $0.01 \mathrm{M}$ acetate buffer solution $(\mathrm{pH}+) .5 \mathrm{~mL}$ aliquot was passed through the column of XAD-16-TAM at a flow rate of $0.2 \mathrm{~mL} / \mathrm{mun}$. After washing with $5 \mathrm{~mL}$ of $0.01 \mathrm{M}$ acetate buffer $(\mathrm{pH}+)$ and 5 $\mathrm{mL}$ of distilled water. the metal ions sorbed on the chelating resin were desorbed with $20 \mathrm{~mL}$ of $0.1-2 \mathrm{M} \mathrm{HCl}_{4} \mathrm{HNO}_{3}$ and $\mathrm{HClO}_{\text {, }}$ at a flow rate of $0.1 \mathrm{~mL} / \mathrm{min}$. The effluent fractions were collected in $3 \mathrm{~mL}$ portions and analyzed for the presence of the metal.

\section{Results and Discussion}

Characteristics of XAD-16-TAM chelating resin. For the identification of functional groups. infrared spectra of the intermediates, the TAM monomer, and XAD-16-TAM chelating resin were analyzed by $\mathrm{KBr}$ pellet method. and the positions of absorption bands corresponding to the functional groups are listed in Table 1. XAD-16-NO_ exhibited two strong bands at 1526 and $1350 \mathrm{~cm}^{-1}$. which are characteristics of nitro groups. However. these bands decreased in the infrared spectrum of XAD-16- $\mathrm{NH}_{2}$ and a strong band due to amine groups were observed at $1626 \mathrm{~cm}^{-1}$. This means that $\mathrm{NO}_{2}$ groups bonded to the XAD-16 reduced to $\mathrm{NH}_{2}$. In the spectrum of XAD-16-TAM. the absorption bands at 1490 and $1400 \mathrm{~cm}^{-1}$ due to the $\mathrm{C}=\mathrm{C}$ and $\mathrm{C}=\mathrm{N}$ stretching vibration 
Table 1. Andy tical data ol the inlennediates, synthesized resin and TAM monomer

\begin{tabular}{|c|c|c|c|c|c|c|c|}
\hline & \multicolumn{4}{|c|}{ lR spectrum of functional group $\left(\mathrm{cm}^{-1}\right)$} & \multicolumn{3}{|c|}{ mmol of functional group g resin } \\
\hline & $V N-O$ & $v \mathrm{~N}-\mathrm{H}$ & $K C-C($ thia. $)$ & $\mathrm{KC}^{-\mathrm{N}}$ (thia.) & $-\mathrm{NO}_{2}^{\prime \prime}$ & $-\mathrm{NH}_{2}^{b}$ & $-\mathrm{TAM}^{\mathrm{c}}$ \\
\hline XAD- 16 resin & - & - & - & - & & & \\
\hline $\mathrm{XAD}-16-\mathrm{NO}_{2}$ & $\begin{array}{l}1526(\mathrm{~s}) \\
1350(\mathrm{~s})\end{array}$ & & & & 5.96 & & \\
\hline $\mathrm{XAD}-16-\mathrm{NH}_{2}$ & - & $1626(s)$ & & & & 3.85 & \\
\hline XAD-16-TAM & & & $1490(\mathrm{~m})$ & $1400(\mathrm{~m})$ & & & 1.21 \\
\hline TAM monomer & & & $1490(\mathrm{ss})$ & $1400(\mathrm{vs})$ & & & \\
\hline
\end{tabular}

thia.: thiazole group. m: medium, s: strong. a.relemental analysis, "non-aqueous titration methon.

of the thiazole group in TAM molecule were observed. From these results, it could be confirmed that TAM molecule was bonded to the $\mathrm{XAD}-16$ resin. The data of elementary analyses of the synthesized resin are listed in Table 1 . The amount of TAM in the resin was $1.21 \mathrm{~mm} / \mathrm{g}$.

The chemical stability was exaluated by measuring the cliange of sorption capacity for Cu(II) after successive contact of XAD-16-TAM with acidic and alkaline solutions in the various concentration range. As a result. the chelating resin was stable in acidic and alkaline solutions below $5 \mathrm{M}$ and could be reused over 5 times.

Sorption of metal ions on XAD-16-TAM resin. The sorption of metal ions on chelating resin is dependent on the $\mathrm{pH}$ of the sample solution due to competitive reaction between chelate forming groups and hydrogen ions in the solutions. The effect of $\mathrm{pH}$ on the sorption of nineteen metal ions in the $\mathrm{pH}$ range $1-6$ was examined by a batch method and the results are presented in Figure 2 and Figure 3. The sorption percent of Zr(IV) was above $90 \%$ at $\mathrm{pH} 1-5$. U(Vl) was above $88 \%$ at $\mathrm{pH} 4$. But the maximum sorption percentage of $\mathrm{Hf}(\mathrm{IV})$ was $79 \%$ at $\mathrm{pH} 3$. The optimum $\mathrm{pH}$ was + for $\mathrm{Cu}(\mathrm{Il})$. Th(IV), Mo(VI) and $\mathrm{W}(\mathrm{Vl}) .5$ for $\mathrm{Nb}(\mathrm{V})$ and $\mathrm{V}(\mathrm{V})$ and +-5 for Ta(V), Fe(llI), Sn(lV). Cr(Ill) and $\ln (l l l)$. The

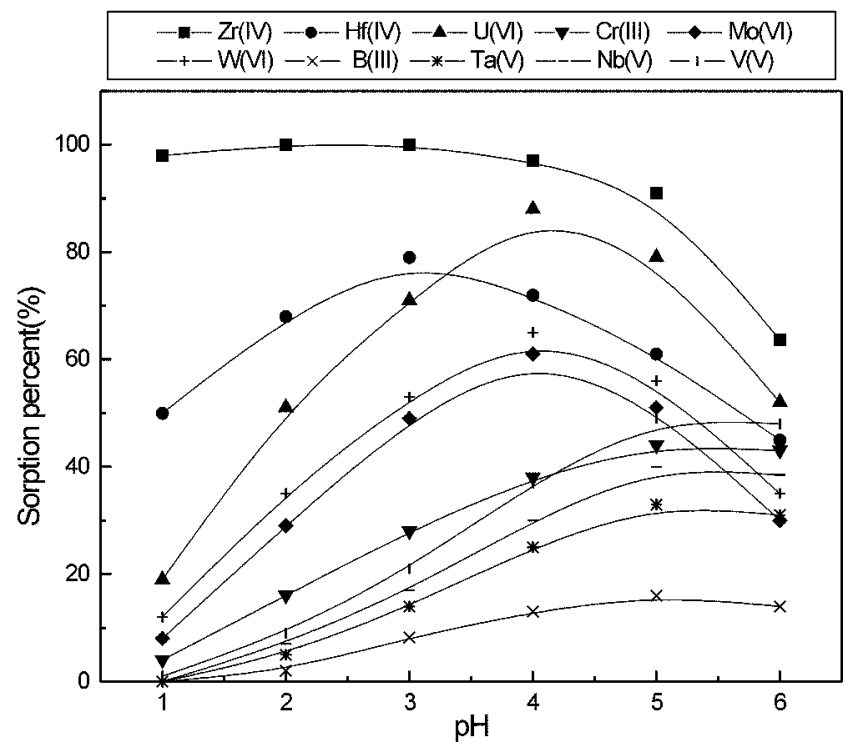

Figure 2. The elfect of pH on sorption of metal ions with XAD-16TAM chclating resin. Resin weight: $50 \mathrm{mg}$. Cons. of metal ions: each $10 \mu \mathrm{g} / \mathrm{mI} / 50 \mathrm{~m}$ I I Slaking time: 24 liss.

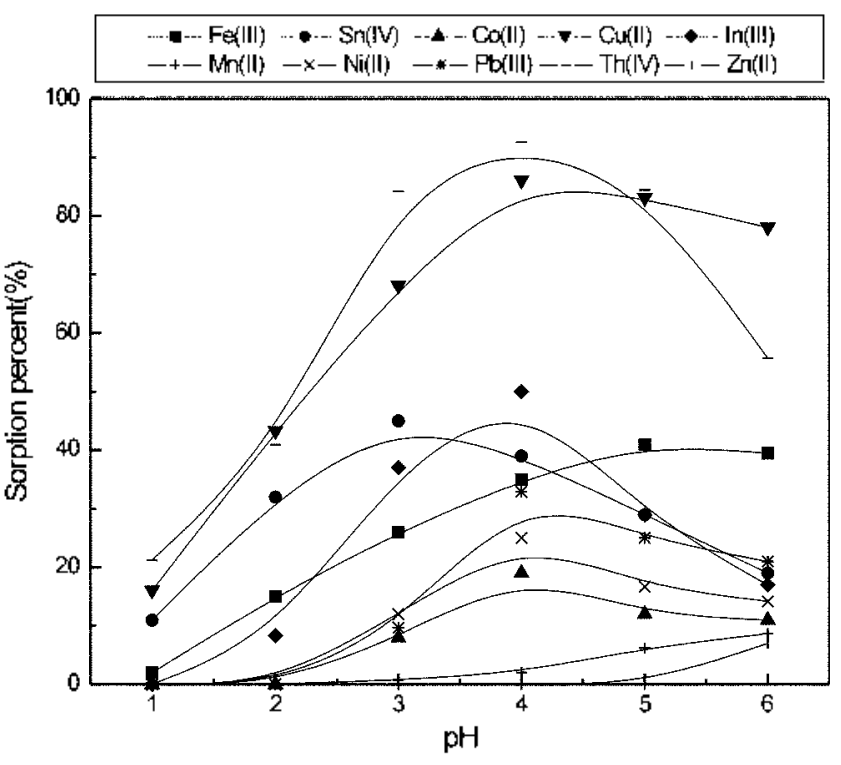

Figure 3. Fffect of $\mathrm{pH}$ on sorption of metal ions with $\mathrm{X} \wedge \mathrm{D}-16$ IAM chelating resin. Resin weight: $50 \mathrm{mg}$, Conc. of metal ions: ach $10 \mu \mathrm{g} / \mathrm{mL} / 50 \mathrm{~mL}$, Shaking time: $24 \mathrm{hrs}$.

selectivity order of metal ions was evaluated as follows: $\mathrm{Zr}(\mathrm{lV})>\mathrm{Th}(\mathrm{IV})>\mathrm{U}(\mathrm{VI})>\mathrm{Cu}(\mathrm{Il})>\mathrm{Hf}(\mathrm{IV})>\mathrm{W}(\mathrm{VI})>\mathrm{Mo}$ (VI) $>\mathrm{In}(\mathrm{III})>\mathrm{V}(\mathrm{V})>\mathrm{Sn}(\mathrm{IV})>\mathrm{Cr}$ (III) $>\mathrm{Fe}(\mathrm{III})>\mathrm{Nb}$ (V) $>$ $\mathrm{Ta}(\mathrm{V})>\mathrm{Pb}($ II $)>\mathrm{Ni}(\mathrm{Il})>\mathrm{Co}(\mathrm{II})>\mathrm{Mn}(\mathrm{II})>\mathrm{Zn}$ (II). This order was in good agreement with that of Ining-Williams series $^{\mid s i}$ and also the stability constants of the chelates formed between TAM and the metal ions. ${ }^{\text {? }}$

Mechanism and kinetics of the sorption. Kinetics of the sorption was studied using $\operatorname{Zr}(\mathrm{IV})$. which showed the best sorption affinity for the resin. As shown in Figure th the sorption was fast and the time taken to reach equilibrium was about 2 hr. This demonstrates that XAD-16-TAM was suitable for the ion chromatographic separation of the metal ions studied.

According to earlier reports. ${ }^{|8-2|}$ the exchange reaction. which is the sorption procedure of metal ions, was regarded as taking place through two mechanisms of film diffusion and particle diffusion. The rate-determining step is particle diffusion. diffusion through the ion-exchange particle. in the following equations derived by Boyd $e t a l^{.2}$

$$
F=1-\frac{6}{\pi^{2}} \sum_{n=1}^{\infty} \frac{1}{n^{2}} \operatorname{cxp}\left(-n^{2} B t\right)
$$




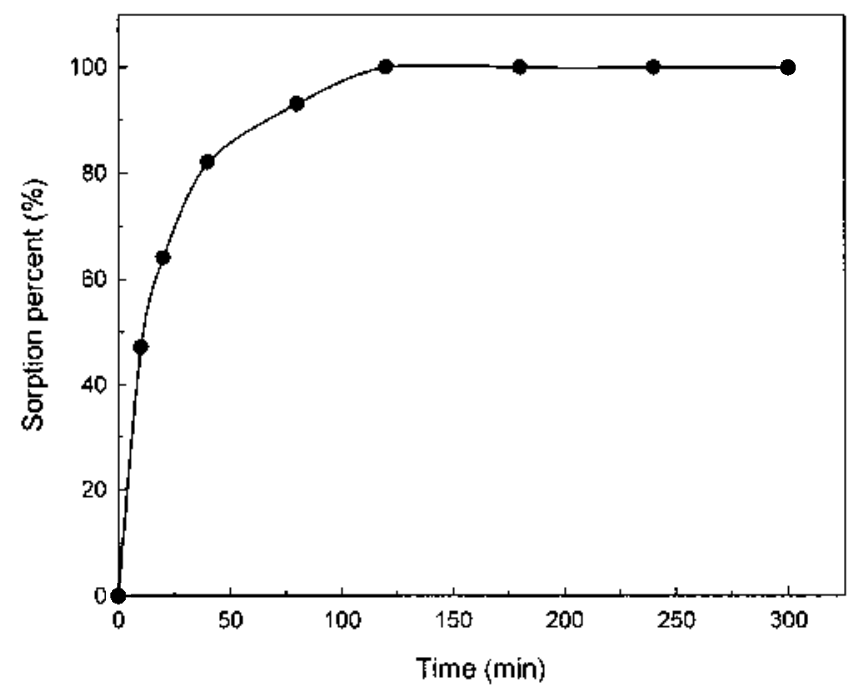

Figure 4 . Sorption equilibrium of $X \wedge D-16-T A M$ chelating resin according 10 shaking time. Resin weight: $30 \mathrm{mg}$. Conc. of metal ion: $\angle \mathrm{T}(\mathrm{IV}) 10 \mu \mathrm{g} / \mathrm{mL} / 30 \mathrm{~mL}$, Matrix: pII 3.0.01 M IIAc-NII.Ac buffer solution.

Where, $F$ is (the amount of exchange at time $\mathrm{t}$ )/(the amount of exchange at infinite time) and $B$ is sorption rate. The equation (2) between $F$ and time $t$ developed by Boyd. et $a l$. expresses this relationship

$$
-\ln (1-F)=k d t
$$

Where, $k_{d}$ is sorption rate constant. From the equation (1) and (2). equation (3) is obtained.

$$
-\ln (1-F)=c B t=k d t
$$

Where, $c$ is a constant. Therefore. if a linear plot of $B t v s, t$ is obtained the rate-determining step can be expected as

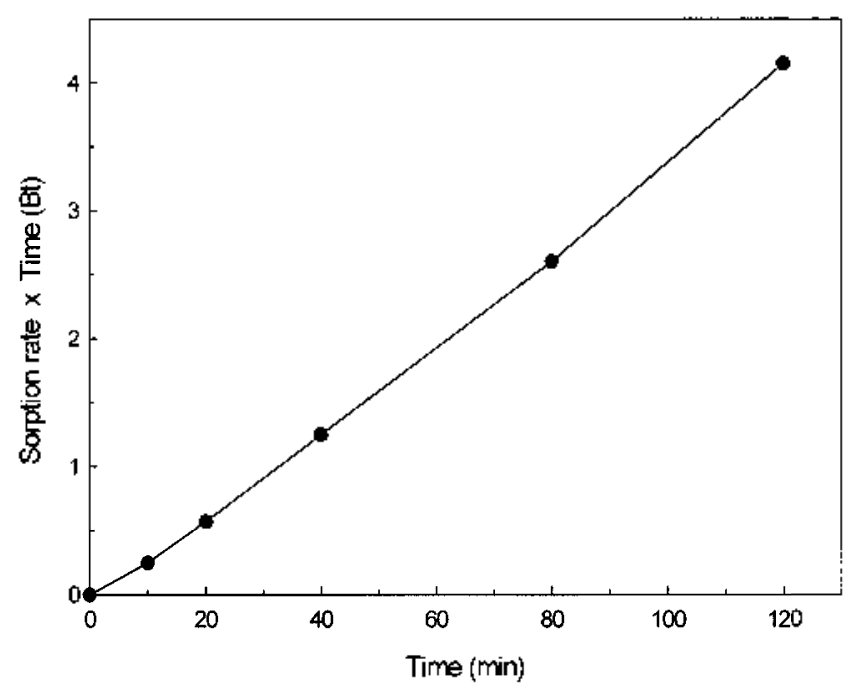

Figure 5, Sorplion rate of XAD-16-TAM chelating resin according to shaking time. Resin wejght: 30 mg, Conc. of metal ion: $7 . x($ IV) $10 \mu \mathrm{g} / \mathrm{mL} / \mathrm{s} 0 \mathrm{~mJ}$, Matrix: ${ }_{3} \mathrm{H}$ 3, $0.01 \mathrm{M} \mathrm{H} \wedge \mathrm{c}-\mathrm{NH}_{4} \wedge \mathrm{c}$ buffer solution. particle diffusion.

In the present study, $F$ was obtained from the sorption percent change of $\operatorname{Zr}(I V)$ according to the shaking time and $B t$ was obtained from $F$ value. Reichenberg ${ }^{2.3}$ gives values of $B t$ for each $F$ values. As shown in Figure 5. the plot of $B t w s$. $t$ was linear. Therefore, it can be seen that the ratedetemining step is diffusion through the particle.

Effect of masking agent on the sorption of metal ions. In this work. applicability of masking agents such as CDTA. EDTA. and NTA to further selective separation of metal ion from a mixed-metal solution was investigated. The results are illustrated in Figures 6-8. As shown in Figure 6, when 2$5 \mathrm{mM}$ of CDTA were added. the sorption percentages of $\mathrm{Fe}(\mathrm{IIl})$. $\mathrm{Cr}(\mathrm{III})$ and $\mathrm{Ta}(\mathrm{V})$ were less than $30 \%$. When the amount added was more than $5 \mathrm{mM}$. the sorption percentages of most ions containing $\mathrm{Zr}(\mathrm{IV}) . \mathrm{Hf}(\mathrm{IV})$ and $\mathrm{Th}(\mathrm{V})$ decreased. But. CDTA had little effect on the sorption of U(VI) for the addition of $5 \mathrm{mM}$ CDTA. The effect of EDTA on sorption of metal ions is shown in Figure 7 . When the amount of EDTA added exceeded $2 \mathrm{mM} . \mathrm{Mn}$ (II) and $\mathrm{Ni}(\mathrm{II})$ did not sorb entirely, and $\mathrm{Co}(\mathrm{II}) . \mathrm{Ta}(\mathrm{V}) . \mathrm{Nb}(\mathrm{V})$ and $\mathrm{V}(\mathrm{VI})$ did not sorb at amounts of EDTA that exceeded $5 \mathrm{mM}$. Adding $10 \mathrm{mM}$ EDTA. the sorption percentage of $\mathrm{Pb}(1 \mathrm{ll})$. Fe(III). Cr(lll) and Sn(IV) was less than $10 \%$. And according to the result of the previous paper. ${ }^{8}$ the sorption percentage of $\mathrm{Zr}(\mathrm{lV})$ was more than $80 \%$ for $5 \mathrm{mM}$ EDTA. This indicate that EDTA can be effectively used as a masking agent for the selective separation of $\mathrm{Zr}$ (IV) from the other metal ions. In Figure 8. the metal ions except for U(Vl) did not sorb in more than over $5 \mathrm{mM} \mathrm{NTA}$. Zr(IV). Th(IV), $\mathrm{Hf}(\mathrm{IV})$ and $\mathrm{Cu}(\mathrm{Il})$ had low sorption percentage of less than $30 \%$ in $10 \mathrm{mM}$ NTA solution. But. the sorption percentage of U(Vl) was $80 \%$ for $5 \mathrm{mM}$ NTA. So U(Vl) can separate

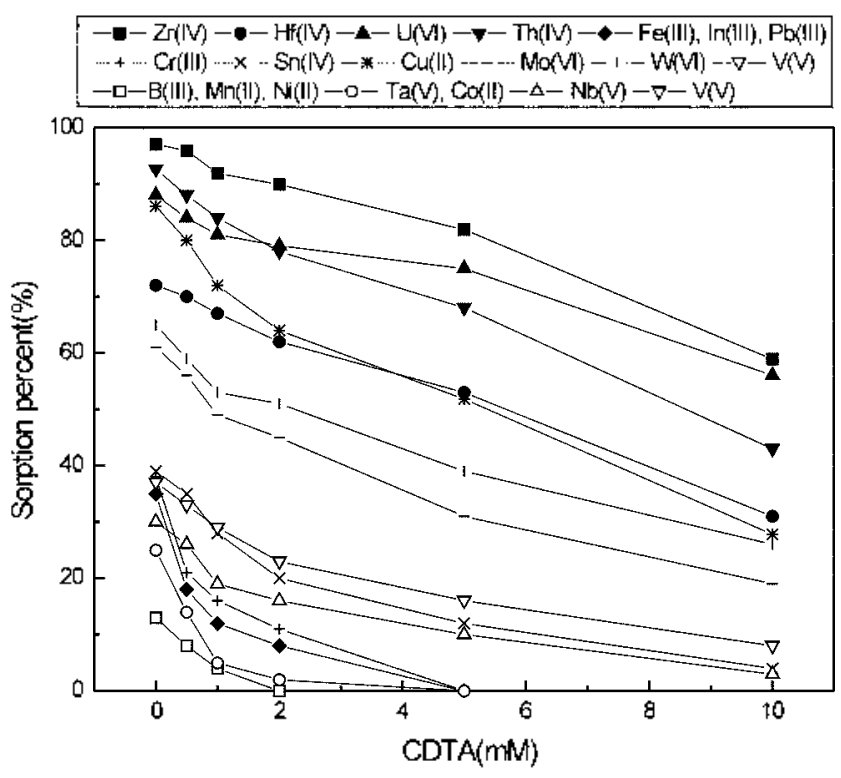

Figure 6. The Elfect of CDTA concentration on sorption of metal ions with XAD-16-IAM cholating resin. Resin weight: $50 \mathrm{mg}$. Conc of metal ions: each $10 \mu \mathrm{c} / \mathrm{mL} / 50 \mathrm{~mL}$., Matrix: $\mathrm{pH}+0.01 \mathrm{M}$ $\mathrm{HAc}-\mathrm{NH}_{+} \wedge \mathrm{c}$ butfer solution, Shaking time: 24 hrs. 


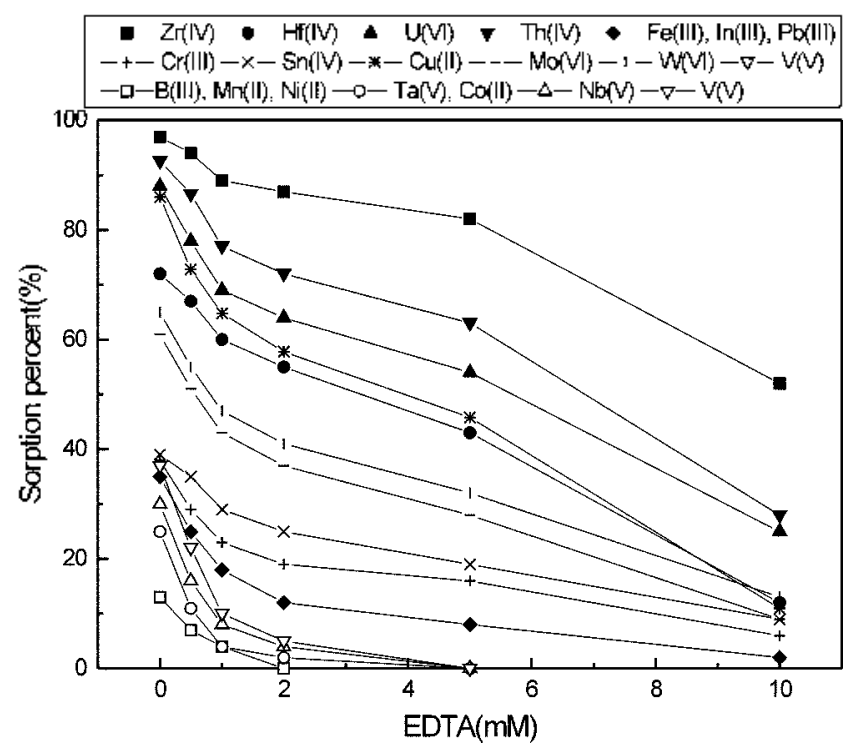

Figure 7. 'The ellect of LD'lA concentration on sorption of metal ions with XAD-16-TAM chelating tesin. Resin weight: $50 \mathrm{mg}$. Conc. of metal ions: each $10 \mu \mathrm{o} / \mathrm{mI} / 50 \mathrm{mI}$, Matrix: $\mathrm{pH} 4,0.01 \mathrm{M}$ I AAc-NII,Ac buller solution. Shaking time: $2+$ hrs.

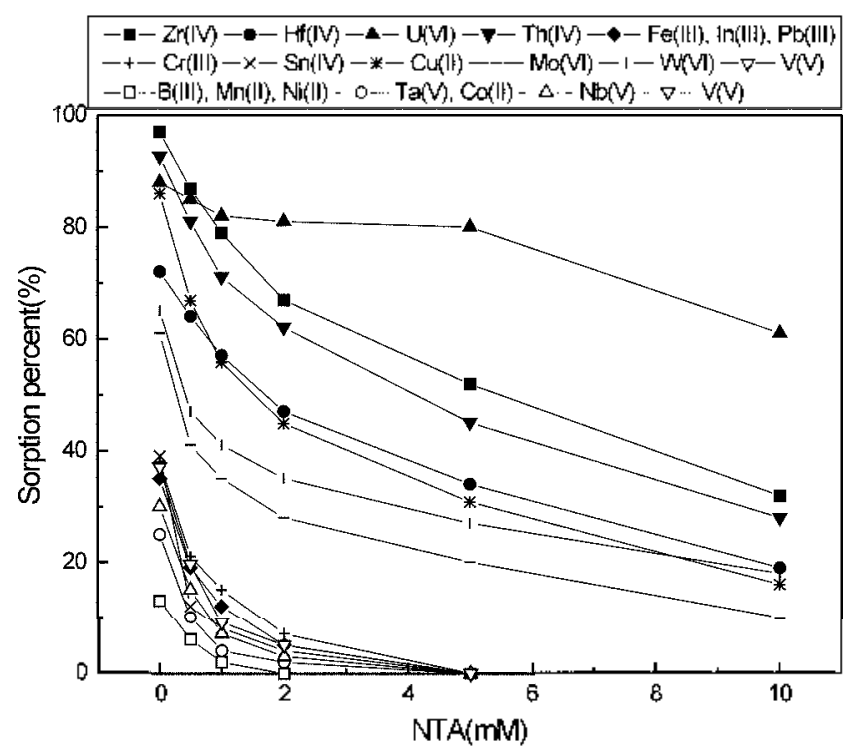

Figure 8. 'The stlect of NTA concentration on sorption of metal ions wilh XAD-16-TAM chelating resin. Resin weight: $50 \mathrm{mg}$, Conc. of metal ions: each $10 \mu / \mathrm{m} / \mathrm{m} / 50 \mathrm{mI}$, Matrix: $1 \mathrm{H} 4,0.01 \mathrm{M}$ $\mathrm{H} \wedge \mathrm{c}-\mathrm{NH}_{4} \wedge \mathrm{c}$ buffèt solution, Shaking time: $24 \mathrm{hrs}$

selectively from other coexisting metal ions. using $5 \mathrm{mM}$ NTA solution. From these results. the masking effect of NTA for most of the metal ions except U(VI) was very large. The masking effect of CDTA and EDTA was similar but for more than $5 \mathrm{mM}$. the masking effect of EDTA was large

Column breakthrough studies. In the present work the metal sorption capacity of XAD-16-TAM was measured to estimate how large a quantity of the chelating resin would be needed for quantitative recovery of an interesting metal ion from an aqueous solution. For the optimum chromatographic condition. the effect of a flow rate on the sorption of metal

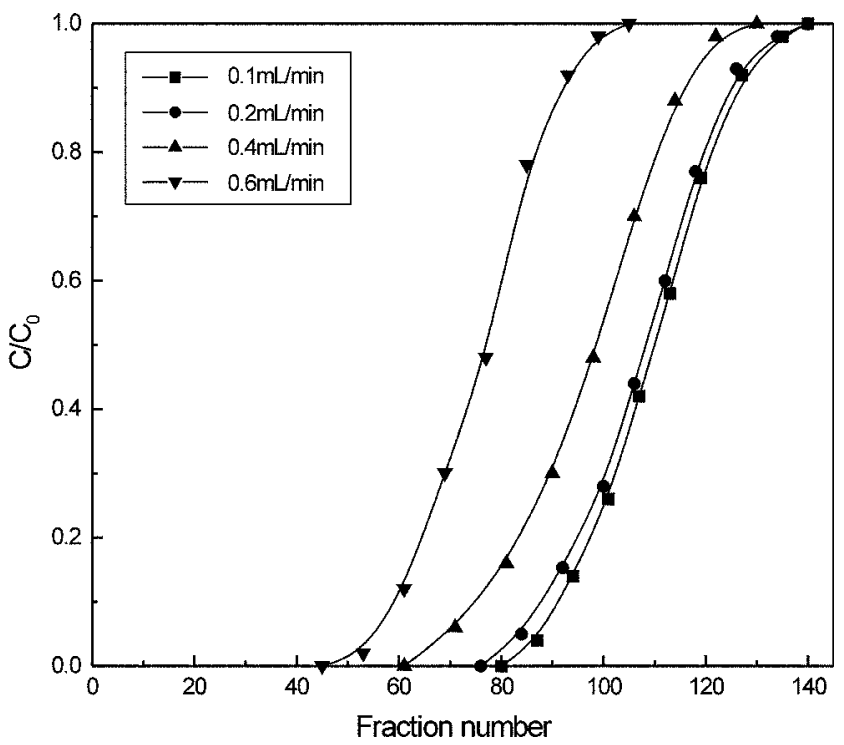

Figure 9. The ellect of flow rale on sorption of metal ion with XAD-16-lAM chelating resin. Resin weight: $50 \mathrm{mg}$. Conce of metal ion: Cu(II) $10 \mu \mathrm{g} / \mathrm{mI}$, Matrix: $\mathrm{pH} 4,0.01 \mathrm{M} \mathrm{H} \Lambda \mathrm{c}-\mathrm{NH}_{+} \Lambda \mathrm{c}$ buffer solution, I Fraction: $5 \mathrm{mI}$.

ions was investigated with $\mathrm{Cu}(\mathrm{II})$. showing a high sorption percentage respectively. Overall capacity was calculated by measuring amount of $\mathrm{Cu}(\mathrm{II})$ sorbed on XAD-16-TAM at the point where $\mathrm{C} / \mathrm{C}_{(, .}, i, e_{. .}$the $\mathrm{Cu}(\mathrm{II})$ concentration ratio of the effluent to influent, was 0.5 on the breakthrough curves, and breakthrough capacity. $\mathrm{C} / \mathrm{C}_{1}$, was 0.01 . As shown in Figure 9. the breakthrough and overall capacity decreased with an increasing flow rate from 0.1 to $0.6 \mathrm{~mL} / \mathrm{min}$. This is probably because retention time of metal ion on the chelating resin increased with decreasing flow rate. But the capacities at the flow rate of $0.1-0.2 \mathrm{~mL} / \mathrm{min}$ showed little difference.

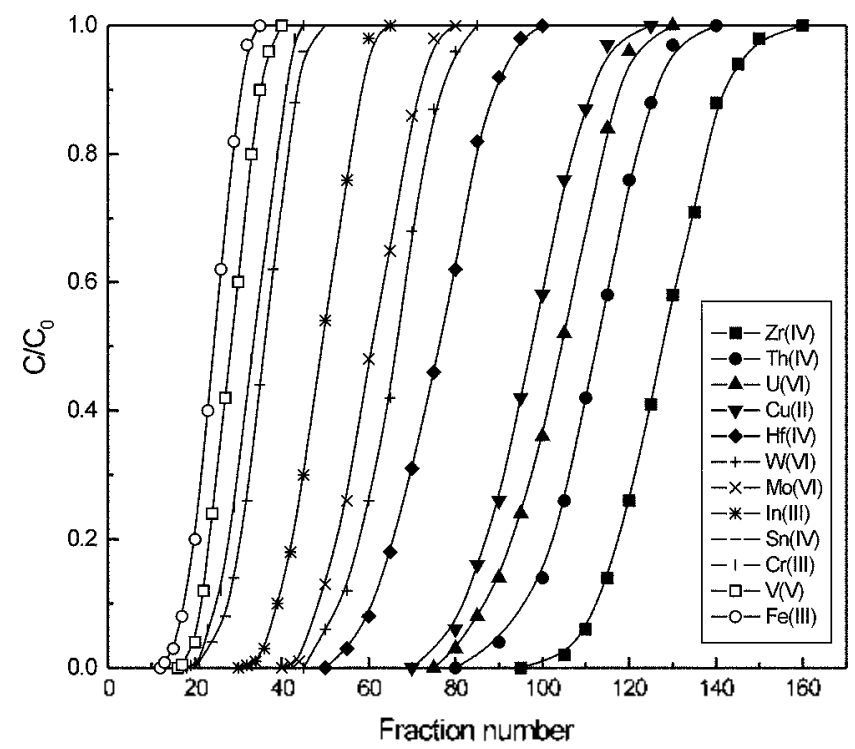

Figure 10. The breakthrough clrves of metal ions with XAD-16TAM chelating resin. Resin weight: $100 \mathrm{mg}$. Conc. of metal ions: ach $5 \mu \mathrm{g} / \mathrm{mL}$, Matrix: pII 4. $01 \mathrm{M} \mathrm{HAC-NH} H_{1}$ Ac butlis solution. Flow rale: $0.2 \mathrm{~mL} / \mathrm{min}, 1$ Fraction: $5 \mathrm{~mL}$. 
Table 2. Breakthrough capacity and overall capacity of metal ions with XAD-16-'LAM cheluting resin

\begin{tabular}{ccc}
\hline \multirow{2}{*}{ Metal ion } & 13reakihrough capacily & Orerall capacity \\
\cline { 2 - 3 } & \multicolumn{2}{c}{ mmol g resin } \\
\hline Zr(IV) & 0.72 & 0.90 \\
Thr(IV) & 0.66 & 0.84 \\
U(VI) & 0.62 & 0.80 \\
Cu(II) & 0.60 & 0.79 \\
Hf(IV) & 0.49 & 0.65 \\
W(VI) & 0.43 & 0.58 \\
Mo(VI) & 0.39 & 0.54 \\
In(III) & 0.31 & 0.43 \\
Sn(IV) & 0.22 & 0.32 \\
Cr(III) & 0.21 & 0.31 \\
V(V) & 0.20 & 0.30 \\
Fo(III) & 0.18 & 0.28 \\
\hline
\end{tabular}

Resin weight: $100 \mathrm{mg}$. Conc. of metal ions: cach $5 / \mathrm{g}$ mI.. Matrix: pI 4. $0.01 \mathrm{M} \mathrm{HAc}-\mathrm{NH}_{4} \mathrm{Ac}$ buffer solution. Flon rale: $0.2 \mathrm{~mL}$ min. 1 Fraction: $5 \mathrm{ml}$.

Therefore, the optimum flow rate was $0.2 \mathrm{~mL} / \mathrm{min}$ for shorter elution time. For a flow rate of $0.2 \mathrm{~mL} / \mathrm{min}$ breakthrough curves of the twelve metal ions. such as $\operatorname{Zr}(I V)$. Th(IV). U(Vl), Cu(ll), Hf(IV). W(Vl). Mo(Vl), In(III). Sn(lV). Cr (III). V(V), Fe(llI), are shown in Figure 10. The inflections of the breakthrough curves showed good symmetry for a volume corresponding to one half of the initial concentration $\left(C_{1} / 2\right)$. This indicated that it should be possible to separate selectively these metal ions from the mixture of metal ions using XAD-16-TAM. ${ }^{2+}$ The resulting breakthrough and overall capacities are listed in Table 2 . The elution order of metal ions was evaluated as $\operatorname{Zr}(\mathrm{IV})>\mathrm{Th}(\mathrm{IV})>\mathrm{U}(\mathrm{Vl})>$ $\mathrm{Cu}(\mathrm{ll})>\mathrm{Hf}(\mathrm{IV})>\mathrm{W}(\mathrm{Vl})>\mathrm{Mo}(\mathrm{VI})>\ln (\mathrm{ll})>\mathrm{Sn}(\mathrm{IV})>$ $\mathrm{Cr}(\mathrm{III})>\mathrm{V}(\mathrm{V})>\mathrm{Fe}(\mathrm{III})$ at $\mathrm{pH}+$. The breakthrough capacity and overall capacity of $\operatorname{Zr}(\mathrm{IV})$, which were higher than the

Table 3. The desorption of inctal ions on various desorption agents with XAD-16-TAM chelating resin

\begin{tabular}{|c|c|c|c|}
\hline \multirow{2}{*}{ Metal ion } & \multicolumn{3}{|c|}{ Recovery $\left({ }^{\circ}{ }^{0}\right)$} \\
\hline & $2 \mathrm{M} \mathrm{HClO}_{1}$ & $2 \mathrm{M} \mathrm{HCl}$ & $2 \mathrm{M} \mathrm{HNO}_{3}$ \\
\hline$/ \mathrm{r}(\mathrm{IV})$ & 100 & 98 & 25 \\
\hline $\operatorname{Th}(\mathrm{IV})$ & 92 & 1000 & 95 \\
\hline U(VI) & 77 & 75 & $I(1)$ \\
\hline Cu(1I) & 26 & 4.3 & $1(10)$ \\
\hline IJI(IV) & 95 & 100 & $10(k)$ \\
\hline W(VI) & 90 & .34 & 70 \\
\hline $\operatorname{Mo}(\mathrm{VI})$ & 88 & 28 & 74 \\
\hline $\ln (111)$ & 34 & 50 & $1(1)$ \\
\hline $\operatorname{Sn}(I V)$ & 57 & 25 & $\mathrm{It}(\mathrm{l})$ \\
\hline $\operatorname{Cr}(\mathrm{IJI})$ & 43 & 26 & $1(10)$ \\
\hline $\mathrm{V}(\mathrm{V})$ & 51 & 88 & 58 \\
\hline ]e(IJl) & 48 & 45 & $1(1)$ \\
\hline
\end{tabular}

Resin weight: $100 \mathrm{mg}$. Conc. of metal ions: each 5 Hg mL. Sorption flow rate: $0.2 \mathrm{~mJ}$. min. Desorption flow rate: $0.1 \mathrm{mI}$. min, Desorption agent iolume: cach $15 \mathrm{mI}$. other metal ions, were 0.72 and $0.90 \mathrm{mmol} / \mathrm{g}$. The breakthrough capacity of $U(V I)$ was $0.80 \mathrm{mmol} / \mathrm{g}$. this value was higher than for XAD-16-TAN in a previous study." respectively: $U(V)$ was more selectively sorbed on the chelating resin and the ratio of breakthrough capacity to overall capacity was 0.78 . These results show that XAD-16-TAM was used effectively for the separation and condensation of U(VI).

Desorption of metal ions. For the quantitative recovery of trace metal ions and reuse of resin. claracteristics of desorption were investigated with desorption agents. such as $\mathrm{HClO}_{1} . \mathrm{HCl}$ and $\mathrm{HNO}_{3}$ at a flow rate of $0.1 \mathrm{~mL} / \mathrm{min}$. The results listed in Table 3 show that $\mathrm{Zr}$ (IV) and $\mathrm{Hf}$ (IV) were at least $95 \%$ recovered by elution with $2 \mathrm{M} \mathrm{HCl}$ and $2 \mathrm{M}$ $\mathrm{HClO}$. . With $\mathrm{HCl}$, the high desorption percent was considered because $\mathrm{Zr}(\mathrm{IV})$ and $\mathrm{Hf}(\mathrm{IV})$ formed a stable complex of $\mathrm{ZrCl}_{6}{ }^{--}$and $\mathrm{HfCl}_{6}{ }^{--}$with $\mathrm{Cl}^{-}$. In $2 \mathrm{M} \mathrm{HNO}_{3}$ solution. recovery percentage of $\mathrm{Zr}(\mathrm{IV})$ was $25 \%$. This result was attributed to $\operatorname{Zr}$ (IV) 's low stability constant of complex with $\mathrm{NO}_{3}{ }^{-}\left(\log \mathrm{K}_{17}=0.8\right)$. Most of the metal ions, except $\mathrm{Zr}(\mathrm{IV})$, were completely recovered using $2 \mathrm{M} \mathrm{HNO}_{3}$. As shown in these results. we expect that $\mathrm{Zr}(\mathrm{IV})$ can be separated selectively from other metal ions.

Acknowledgment. This work was supported by grant No. (1999-1-124-001-3) from the interdisciplinary research program of the KOSEF.

\section{References}

1. Schmuckler. D. Talanta 1963. 10.745.

2. Degello. S.: Faguin. M.: Moresco. A.: Baracco. L. Bull Chem. Soc.Jph. 1983.56.904.

3. de Moracs. S.: Abrao. A. Anat Chem. 1974. \$6, 1812.

4. I.ce, C. II.: Suh. M. Y.: Joe, K. S.: Fom, T. Y.: I .ce, W. Anat Chim. Acta 1997, 351, 57.

5. Chwastowska. J.: Mozer. M. Falanta 1985. 32. 7.

6. Curberg. G. E.: Boren. H.: Grimvall. A.: Lundgren. B. V. .7. of (homatograph 1987.39/.169).

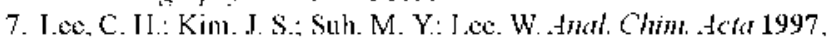
$3.39,30.3$

8. I.ce, W. I.ee. S. F.. I.ce. C. II.: Kim. Y. S. I.ce. Y. I. Hicrochem. J. 2001.35 .195$.

9. Salters. V. I. M. . Whal (Them. 1994. 66. 4186

10. Yang. X. I.: Pin. C. Itwal Chem. 1999. 7l. 1706

11. Clang. R. C.: Fritz. J. S. Tatom/a 1978. 25, 659.

12. Saxela, R.: Singh, A. K.: Sambi. S. S. Anat Chim .tcta 1994. 295,199

13. Wada. H.: Nakagawa. G. Lhal left. 1968. 1.687.

14. Eshwar. M. C.: Sharma. C. D. Wicmohem. J. 1987. 35. 27.

15. Ying. L. L.: De. G. M.: Qiu. L. Y. Talanta 1995. 42.1.

16. Irving. H.; Williams, R. Katwe 19+8, 162.746.

17. Andersom, R. G.; Nickless, (i. - thatyst 1967,92, 109.3

18. Rawat. I. P.; Thind, P. S. J. Jhys. Chem. 1976. 80. 1.384.

19. Nachod. F. C.: Wood. W. J. Im. (them. Soc. 1944. 66. 1380.

20. Nachod. F. C.: Wood. W. J. tm. (he'm. Soc. 1945. 67. 629.

21. Turse. R.: Rieman. W. J. Phis (hem 1961. 65. 1821.

22. Bovd, G. F.: Adamson, $\wedge$. W: Mvers, I. S. J. Am Chem Soc. $19+7,69,28.36$

23. Reichenberg. D. J. Am. Chem. Soc. 1953,75,589

24. Svodova L.: Jandera. P.: Churacek. I. Collet. ('ze'ch Chem. Commm 1991.56.317. 